\title{
Urban Teenagers Talk about Leisure Reading
}

\author{
Sandra Hughes-Hassell \\ Associate Professor \\ School of Information \& Library Science \\ The University of North Carolina at Chapel Hill \\ United States
}

\begin{abstract}
In urban school districts in the United States, it is not unusual for 80 percent of the eighth-graders to read below grade level. Schools are tackling low literacy levels by initiating literacy programs, many of which contain a focus on building the habit of leisure reading. While research has shown a connection between success in school and the amount of leisure reading students do, little is known about the leisure reading habits of urban teenagers. This paper reports the results of a three-part study investigating the leisure reading behaviors of urban teenagers and suggests strategies to support their literacy development.
\end{abstract}

Urban teenagers, leisure reading, adolescent literacy

\section{Introduction}

Strong literacy skills are necessary to succeed in school and in life. Individuals who do not have these skills find themselves at a serious disadvantage "in social settings, as civil participants, and in the working world" (Biancarosa \& Snow, 2006, p. 3). Yet, 74 percent of American eighth-graders are reading below grade level nationwide (NCES, 2007). In urban communities only an estimated 20 percent of students are reading at grade level and thus are prepared to master high school-level content (Balfanz, Spiridakis, \& Neild, 2002; Biancarosa $\&$ Snow, 2006). As Biancarosa and Snow (2006) point out, in the era of the No Child Left Behind (NCLB) Act performing below grade level in reading carries increasingly higher stakes for retention and ultimately the withholding of high school diplomas.

Difficulty with reading negatively impacts achievement in all areas of the curriculum. According to Schoenbach, Greenleaf, Cziko, and Hurwitz (2000), many adolescents, hit a "literacy ceiling" when they reach middle and high school. That is, they are unable to "independently access the knowledge and information embedded in the books and other printed materials that are part of a curriculum" (Schoenbach et al., 2000, p. 5). This inability interferes with their capacity to accomplish the challenging work necessary to meet high academic standards. Teachers and students alike become frustrated. Students come to think of themselves as non-readers or poor readers. Many avoid reading, waiting for the teacher to tell them what they need to do. Others attempt to become invisible, while still others act out, creating distractions to cover up their inadequacies.

Many schools have begun to tackle the problem of reading in the middle- and highschool years by initiating adolescent literacy initiatives. A common element found in wellregarded programs is a focus on building the habit of leisure reading (McGrath, 2005). Both qualitative and quantitative studies have demonstrated a correlation between success in school and the amount of leisure reading students do (c.f. Allington \& McGill-Franzen, 2003; Krashen, 1993, 2004). While numerous researchers have surveyed the leisure reading habits of adolescents, urban youth have accounted for only a small percentage of the respondents. 
If, as the research indicates, there is a strong relationship between leisure reading and school achievement, it only makes sense that educators develop an understanding of the leisure reading habits of urban adolescents. This paper reports the findings of a three-part study investigating the leisure reading habits of 826 urban middle and high school students. The study investigated five aspects of urban teen leisure reading: 1) Do urban teenagers read in their leisure time; 2) If they read, what do they read, when do they read, and why do they read; 3) What topics and types of characters or people do they like to read about; 4) How do they obtain their reading material; and 5) Who encourages them to read?

\section{Literature Review}

\section{Leisure Reading Defined}

Leisure reading is the reading students choose to do on their own, as opposed to reading that is assigned to them (Mellon, 1987). Also referred to as free voluntary reading (Krashen, 1993, 2004; Short, 1995), spare time reading (Searls, 1985), recreational reading (Manzo \& Manzo 1995), independent reading (Cullinan, 2000), reading outside of school (Anderson, Wilson, \& Fielding, 1988), and self-selected reading (Worthy, Turner, and Moorman, 1998), leisure reading involves personal choice, choosing what one wants to read, and reading widely from a variety of sources — not just books.

\section{Teenagers and Leisure Reading}

Numerous research studies conducted over the last twenty years show that, contrary to popular opinion, teenagers do read. As Aronson (2001) points out, if this were not true, "how else would they install new programs, pass driving tests, select precisely the right clothing and look, know all about their favorite teams, stars, musicians, and even writers if they weren't constantly reading" (p. 101).

The Mellon poll, administered to 362 ninth graders in two rural high schools in North Carolina, found that 82 percent of the students said they read in their spare time (Mellon 1987). Moffitt and Wartella (1992) reported similar findings in their study of the leisure reading habits of 414 high school students in central Illinois; 78 percent of the students claimed to read books for pleasure.

In 1999 SmartGirl, in cooperation with the Young Adult Library Services Association's (YALSA) Teen Read campaign, posted a reading survey to their Web site. Twenty-six percent of the 3000 teens responding reported reading constantly for their own pleasure; 46 percent said they didn't read much for pleasure, but they liked to read when they got a chance (SmartGirl 1999). This survey has been conducted each year since 1999 with similar results.

The READ California poll, conducted for the California State Department of Education in 1999, surveyed 201 adolescents. Eighty-five percent of the respondents said they read outside of school (Krashen 2001). A nationwide survey conducted in 2001 by Hart (2001) for the National Education Association, found that teens rate reading higher in importance in terms of its impact on their future success than they do math, science, and even computers. Eighty-seven percent of the 509 teens polled say they find reading relaxing; 85 percent view it as rewarding and satisfying; and 79 percent consider it stimulating and 
exciting. Finally, Kaczmarek \& Stachowiak (2004) surveyed 163 girls attending a Catholic high school. Ninety percent of the students said they enjoy reading. Freshmen tended to read the least, with upperclassmen averaging three hours per week.

\section{Leisure Reading and School Success}

Both qualitative and quantitative studies demonstrate a correlation between success in school and the amount of leisure reading students do (Anderson, Fielding \& Wilson, 1988; Allington \& McGill-Franzen, 2003; Krashen, 2004). The amount of leisure reading done outside of school has consistently been found to relate to achievement in vocabulary, reading comprehension, verbal fluency, and content knowledge (Ruetzel \& Hollingsworth, 1991; Short, 1995). Students who read in their spare time become better readers, score higher on achievement tests in all subject areas, and have more content knowledge than those who do not (Cunningham \& Stanovich, 1991). According to Krashen (1993), "although free voluntary reading alone will not ensure attainment of the highest levels of literacy, it will at least ensure an acceptable level" (p. 84).

\section{Methodology}

This three-part study was conducted in two middle schools and one high school in the United States. Part 1 was conducted in a small urban middle school in a large Northeastern city. ${ }^{1}$ Two-hundred forty-five students attend the school which serves grades six through eight as an alternative middle school. Twenty-one percent of the students are Caucasian, 73 percent African-American, three percent Hispanic, and three percent Asian American. Sixtyone percent of the students qualify for free or reduced lunch. Results on the most recent State Assessment of reading indicate that 67 percent of the students are scoring at basic or below basic levels.

Part 2 was conducted in a large urban middle school in the same Northeastern city. ${ }^{2}$ The school serves approximately 1,340 students in grades five through eight. The student body is largely Latino (66\%) and African American (27\%). Eighty-six percent of the students qualify for free or reduced lunch. Results on the most recent State Assessment of reading indicate that 68 percent are performing below basic, 23 percent basic, and nine percent proficient.

Part 3 study participants included 28 tenth and eleventh grade students enrolled in three English classes at a small urban high school in the Southern United States. Fourteen percent of the students were African American, 18 percent were Hispanic, and 68 percent were Caucasian. Four were enrolled in English 10A, a standard level college prep English course; one in English 10B, a lower level English class; and 23 in Honors English 11.

To collect data for Part 1 and Part 2 of the study, middle school teachers administered a five-page, 20-item questionnaire focused on factors related to leisure reading: whether or not adolescents read in their leisure time; if they do, what, when and why they read, the topics and types of characters or people they like to read about, how they obtain their reading material, and who encourages them to read; if they don't read, why not. The questionnaire, adapted from the Smartgirl.com survey (1999), contained 16 multiple choice questions and four open-ended questions: 1) What was your favorite book when you were in elementary 
school? 2) In middle school? 3) What is the best book you've read this year? 4) Is there anything else you'd like to tell us about reading? Students were also asked to indicate their gender and age.

Part 3 employed a range of qualitative and quantitative data collection methods. First, the 28 high school students who volunteered to participate completed a survey designed to assess how they spend their leisure time. The survey, based on surveys used in prior studies focused on the leisure reading of teenagers (SmartGirl.com, 1999; Nipped, Duties, \& Larsen, 2005), included questions about their activities outside of school and their reading practices and materials. Next, 19 of the students volunteered to keep reading logs for one week in February, March and April 2008 in which they recorded the title of anything they read (including websites, social networking sites, instant messaging, email, and text messaging), along with the approximate time spent reading each item. Finally, these 19 students participated in individual interviews in May which focused on their history as a reader.

\section{Findings}

Table 1 provides demographic data for the study participants.

\begin{tabular}{|l|c|c|c|c|}
\hline PARTICIPANTS & $\begin{array}{c}\text { SCHOOL 1 } \\
\text { MIDDLE } \\
\text { SCHOOL }\end{array}$ & $\begin{array}{c}\text { SCHOOL 2 } \\
\text { MIDDLE } \\
\text { SCHOOL }\end{array}$ & $\begin{array}{c}\text { SCHOOL 3 } \\
\text { HIGH } \\
\text { SCHOOL }\end{array}$ & TOTAL \\
\hline Female & 119 & 309 & 14 & 442 \\
\hline Male & 95 & 275 & 14 & 384 \\
\hline Total & 214 & 584 & 28 & 826 \\
\hline
\end{tabular}

Table 1. Study Participants

Data were analyzed to determine what percentage of respondents, both overall and by gender claimed they did or did not read in their spare time. For non-readers, reasons they gave for not reading were examined. For readers, factors relating to types of reading material chosen for leisure reading were analyzed: what, when, why they read; the topics and types of characters or people they like to read about; how they obtain their reading material, and who encourages them to read. Differences in the three schools were also examined.

\section{Reading as a Leisure Activity}

As Table 2 shows, seventy-two percent of the students indicated that they engaged in reading as a leisure activity, a finding which is consistent with the other studies of adolescent reading discussed in the literature review. Twenty-two percent said they read "constantly" and 50 percent indicated they "read when they get a chance." Six percent of the adolescents indicated that they do not read; the other 21 percent said they read only for school. Females were more likely to read for pleasure than males (79\% versus $65 \%)$. This finding too is consistent with previous studies that found that female adolescents were more likely than male adolescents to engage in leisure reading (McKenna et al., 1995; Moffitt \& Wartella, 1992; Simpson, 1996). 


\begin{tabular}{|l|c|c|c|c|}
\hline & $\begin{array}{c}\text { SCHOOL 1 } \\
\text { MIDDLE } \\
\text { SCHOOL }\end{array}$ & $\begin{array}{c}\text { SCHOOL 2 } \\
\text { MIDDLE } \\
\text { SCHOOL }\end{array}$ & $\begin{array}{c}\text { SCHOOL 3 } \\
\text { HIGH } \\
\text { SCHOOL }\end{array}$ & TOTAL \\
\hline $\begin{array}{l}\text { I read constantly for my own personal } \\
\text { satisfaction }\end{array}$ & $24 \%$ & $22 \%$ & $21 \%$ & $22 \%$ \\
\hline $\begin{array}{l}\text { I don't have much time to read for } \\
\text { pleasure but I do it when I can }\end{array}$ & $49 \%$ & $50 \%$ & $54 \%$ & $50 \%$ \\
\hline $\begin{array}{l}\text { I only read what I'm supposed to for } \\
\text { school }\end{array}$ & $22 \%$ & $22 \%$ & $18 \%$ & $21 \%$ \\
\hline I basically don't read much & $6 \%$ & $6 \%$ & $7 \%$ & $6 \%$ \\
\hline
\end{tabular}

Table 2. How often do you read?

The students seemed to do most of their reading after school or at night. Only 16 percent of the students indicated that they read on the weekend. Reading during summer vacation was also not popular with students. Only 22 percent of the students reported that they continue to read for pleasure during the summer months.

\section{Students' Attitudes toward Leisure Reading}

When students were asked if they enjoyed reading, 34 percent responded "yes," 57 percent responded "sometimes," and eight percent responded "no." Again there was some difference between the attitudes of males and females - 40 percent of the girls responded yes as compared to 28 percent of the boys. When asked if they had more time, if they would read more, 34 percent of the students said "yes" and 48 percent responded "probably."

As Table 3 shows, the majority of the students indicated that they read in their spare time for three main reasons: fun and relaxation, to learn new things, and because they get attached to the characters they are reading about. Fun and relaxation were described in a variety of ways. According to one young woman, "reading is really exciting because you can get into the book and imagine the story's characters." A young man echoed her feelings: "I love making my own adventures and fantasies while I read." Others described reading as "fascinating," "colorful," and "better than TV."

\begin{tabular}{|l|c|c|c|c|}
\hline \multicolumn{1}{|c|}{ REASON } & $\begin{array}{c}\text { SCHOOL 1 } \\
\text { MIDDLE } \\
\text { SCHOOL }\end{array}$ & $\begin{array}{c}\text { SCHOOL 2 } \\
\text { MIDDLE } \\
\text { SCHOOL }\end{array}$ & $\begin{array}{c}\text { SCHOOL 3 } \\
\text { HIGH } \\
\text { SCHOOL }\end{array}$ & TOTAL \\
\hline For fun & $57 \%$ & $58 \%$ & $59 \%$ & $57 \%$ \\
\hline It's relaxing & $50 \%$ & $47 \%$ & $55 \%$ & $51 \%$ \\
\hline $\begin{array}{l}\text { I get attached to characters I'm reading } \\
\text { about }\end{array}$ & $55 \%$ & $34 \%$ & $41 \%$ & $43 \%$ \\
\hline To learn something new/it's educational & $42 \%$ & $48 \%$ & $32 \%$ & $41 \%$ \\
\hline It's exciting & $42 \%$ & $35 \%$ & $36 \%$ & $38 \%$ \\
\hline For escape & $22 \%$ & $16 \%$ & $59 \%$ & $33 \%$ \\
\hline For a time filler & $24 \%$ & $17 \%$ & $41 \%$ & $27 \%$ \\
\hline For motivation & $16 \%$ & $16 \%$ & $27 \%$ & $20 \%$ \\
\hline For brain stimulation & $19 \%$ & $24 \%$ & $14 \%$ & $19 \%$ \\
\hline
\end{tabular}

Table 3. If you read, why do you like to read? Check all that apply. 
The students who read to learn new things did so "to get better at it [reading]," and "to gain knowledge." Many of the students recognized that the more they read, the better readers they become. Comments included: "Reading is good for everybody because you learn more about reading;" and "Reading improves your vocabulary." The teenagers who read to "gain knowledge" were interested in satisfying their curiosity about special topics, improving their grades in school, learning English, preparing for college or work, or learning how to cope with obstacles in life. One student for example said she liked to read about "fashion tips and also hairstyles." Several of the male students indicated a preference for reading websites and magazines about their favorite sport. Some students saw reading as a way to improve their grades in school. According to one young woman, "Books are fun to read because you can put your grades up." A number of the students mentioned reading as a way "to learn the [English] language." The high school students in particular recognized reading as critical for success in college and careers. As one of them put it, "it's hard to do certain things in school or on the job if you can't read well." Several of the students used reading as a form of bibliotherapy. One student explained, "I like reading books about kids my age that have been abandoned and abused, like I was. It helps me find new ways to deal and confront it."

The students who indicated that they read because they get attached to the characters they are reading were passionate in their responses. Several of the female high school students, for example, were reading Twilight (Meyers, 2005). When I asked them what was appealing about the book, one replied, "Oh my! Those books...the characters! Edward is... oh, my!" Another young woman explained, "Reading moves me emotionally. I develop relationships with the characters - and they don't argue back!

Those who did not enjoy reading seemed to prefer other activities rather than simply rejecting the act of reading (see table 4). This was especially true for the high school students. Spending time with friends, participating in sports, and surfing the web were more interesting to them than reading. As one young man stated, "There are just too many temptations like the computer, the Internet, and talking to my friends." Their reading logs showed that these students spend an average of two hours and forty-five minutes per day using MySpace, instant messaging, and/or text messaging to keep in touch with their friends. Only two of the 28 students reported spending no time using these social networking technologies.

\begin{tabular}{|l|c|c|c|c|}
\hline \multicolumn{1}{|c|}{ REASON } & $\begin{array}{c}\text { SCHOOL 1 } \\
\text { MIDDLE } \\
\text { SCHOOL }\end{array}$ & $\begin{array}{c}\text { SCHOOL 2 } \\
\text { MIDDLE } \\
\text { SCHOOL }\end{array}$ & $\begin{array}{c}\text { SCHOOL 3 } \\
\text { HIGH } \\
\text { SCHOOL }\end{array}$ & TOTAL \\
\hline Rather spend time with friends & $52 \%$ & $33 \%$ & $83 \%$ & $56 \%$ \\
\hline Rather watch TV & $56 \%$ & $35 \%$ & $67 \%$ & $53 \%$ \\
\hline Like other activities better & $41 \%$ & $32 \%$ & $64 \%$ & $46 \%$ \\
\hline Rather surf the web & $35 \%$ & $29 \%$ & $67 \%$ & $44 \%$ \\
\hline Too busy/no time & $30 \%$ & $27 \%$ & $67 \%$ & $41 \%$ \\
\hline Trouble concentrating & $34 \%$ & $29 \%$ & $40 \%$ & $34 \%$ \\
\hline Rather play video games & $44 \%$ & $24 \%$ & $28 \%$ & $32 \%$ \\
\hline Too much school work & $33 \%$ & $23 \%$ & $39 \%$ & $32 \%$ \\
\hline Can't find a good book & $30 \%$ & $24 \%$ & $39 \%$ & $31 \%$ \\
\hline Can't get into stories & $26 \%$ & $18 \%$ & $28 \%$ & $30 \%$ \\
\hline Reading makes me tired & $25 \%$ & $23 \%$ & $33 \%$ & $27 \%$ \\
\hline Girls more interesting & $23 \%$ & $22 \%$ & $28 \%$ & $24 \%$ \\
\hline Boys more interesting & $18 \%$ & $20 \%$ & $17 \%$ & $18 \%$ \\
\hline Reading is boring/not fun & $20 \%$ & $18 \%$ & $17 \%$ & $18 \%$ \\
\hline
\end{tabular}

Table 4. If you don't read, why not? Check all that apply. 
The lack of appealing resources was another common theme. Comments included: "Libraries should have better books;" "For me reading is fun, but I can't always find the books I like;" and "I wish there were magazines in the library." For the high school students, lack of choice was another prevalent theme. Many of them talked about the books they were "forced" to read in school and described them as boring and having little relevance to their lives. One young woman even remarked that "having to read books I didn't choose for school has made me not enjoy reading."

\section{Leisure Reading Materials}

When asked what they prefer to read, as Table 5 shows, the responses from the middle school students were similar. Magazines were clearly the preferred leisure reading material. Top choices for males included sports, video gaming, and music. The females chose music magazines, followed by fashion and beauty, and video gaming. Comic books/graphic novels and the Internet were also favorites. Books accounted for a smaller percentage of the students' leisure reading materials (37\% and $30 \%)$.

The high school students' responses were quite different. The Internet was clearly their preferred leisure reading material (65\%), followed by books $(57 \%)$, and then magazines $(48 \%)$. When asked why they preferred to read online materials, comments included, "it's easier, more convenient;" "I can be on more than one website at a time;" "it's more interesting;" "there are more choices"; and "I get more recent information." The social nature of the Internet was mentioned by the majority of students as well. As one young woman explained, "I'm more interested in the social. When I'm on the web, my friends are on there too and we can talk to each other."

\begin{tabular}{|c|c|c|c|c|}
\hline MATERIAL & $\begin{array}{c}\text { SCHOOL 1 } \\
\text { MIDDLE } \\
\text { SCHOOL }\end{array}$ & $\begin{array}{c}\text { SCHOOL 2 } \\
\text { MIDDLE } \\
\text { SCHOOL }\end{array}$ & $\begin{array}{c}\text { SCHOOL 3 } \\
\text { HIGH } \\
\text { SCHOOL }\end{array}$ & TOTAL \\
\hline Magazines & $87 \%$ & $72 \%$ & $48 \%$ & $69 \%$ \\
\hline Music & $63 \%$ & $63 \%$ & $36 \%$ & $54 \%$ \\
\hline Sports & $57 \%$ & $42 \%$ & $39 \%$ & $46 \%$ \\
\hline Entertainment & $55 \%$ & $36 \%$ & $46 \%$ & $46 \%$ \\
\hline Fashion/Beauty & $47 \%$ & $40 \%$ & $39 \%$ & $42 \%$ \\
\hline Video game & $48 \%$ & $49 \%$ & $21 \%$ & $39 \%$ \\
\hline Puzzle & $26 \%$ & $35 \%$ & $11 \%$ & $24 \%$ \\
\hline Science & $12 \%$ & $16 \%$ & $7 \%$ & $12 \%$ \\
\hline News & $7 \%$ & $9 \%$ & $7 \%$ & $8 \%$ \\
\hline Internet & $40 \%$ & $37 \%$ & $64 \%$ & $47 \%$ \\
\hline Books for pleasure & $37 \%$ & $30 \%$ & $57 \%$ & $41 \%$ \\
\hline Comics/ Graphic novels & $49 \%$ & $44 \%$ & $18 \%$ & $37 \%$ \\
\hline Newspapers & $17 \%$ & $20 \%$ & $29 \%$ & $22 \%$ \\
\hline
\end{tabular}

Table 5. What do you like to read? Check all that apply?

Another survey question asked the students to indicate the types of characters or people they like to read about. Again, there were differences between the responses of the middle school and high school students (see table 6). The high school students overwhelmingly preferred to read about "people or characters like me" $(71 \%)$. While the middle school students wanted to read about people like themselves (58\% and $43 \%)$, the most popular topic for them was celebrities $(63 \%$ and $56 \%)$. The least popular topic for all three groups was historical figures. 


\begin{tabular}{|l|c|c|c|c|}
\hline $\begin{array}{l}\text { TYPE OF CHARACTER } \\
\text { OR PERSON }\end{array}$ & $\begin{array}{c}\text { SCHOOL 1 } \\
\text { MIDDLE } \\
\text { SCHOOL }\end{array}$ & $\begin{array}{c}\text { SCHOOL 2 } \\
\text { MIDDLE } \\
\text { SCHOOL }\end{array}$ & $\begin{array}{c}\text { SCHOOL 3 } \\
\text { HIGH } \\
\text { SCHOOL }\end{array}$ & TOTAL \\
\hline $\begin{array}{l}\text { People or characters like } \\
\text { me }\end{array}$ & $58 \%$ & $43 \%$ & $71 \%$ & $57 \%$ \\
\hline Celebrities & $63 \%$ & $56 \%$ & $29 \%$ & $49 \%$ \\
\hline $\begin{array}{l}\text { People my age who } \\
\text { have done some cool or } \\
\text { amazing things }\end{array}$ & $47 \%$ & $42 \%$ & $54 \%$ & $48 \%$ \\
\hline Sports figures & $44 \%$ & $43 \%$ & $43 \%$ & $43 \%$ \\
\hline Musicians & $36 \%$ & $42 \%$ & $46 \%$ & $41 \%$ \\
\hline Fantasy characters & $43 \%$ & $38 \%$ & $36 \%$ & $39 \%$ \\
\hline $\begin{array}{l}\text { People or characters a } \\
\text { lot different from me }\end{array}$ & $41 \%$ & $31 \%$ & $43 \%$ & $38 \%$ \\
\hline $\begin{array}{l}\text { People or characters my } \\
\text { age wrestling with tough } \\
\text { issues }\end{array}$ & $44 \%$ & $35 \%$ & $36 \%$ & $38 \%$ \\
\hline Animals & $31 \%$ & $39 \%$ & $0 \%$ & $23 \%$ \\
\hline Historical figures & $21 \%$ & $18 \%$ & $21 \%$ & $20 \%$ \\
\hline
\end{tabular}

Table 6: Which of the following types of characters or people do you like to read about?

\section{Sources}

Students in the two middle schools indicated that they get their reading material from three primary sources: the school library $(65 \%)$, the public library $(53 \%)$, and the classroom $(48 \%)$. The high school students, however, reported that they get most of their reading material from bookstores (54\%). The school library was a source of reading material for only 36 percent of the high school students; the public library for 39 percent. In the interviews these students explained that they mainly use libraries for materials related to school projects, not for leisure reading materials.

\section{Specific Influences}

The final factor studied was who encourages these adolescents to read. Not surprisingly, parents and teachers topped the list, with 72 percent of the teenagers choosing parents and 65 percent choosing teachers. Overall, librarians were chosen by 40 percent of the students - 26 percent of the students selected school library media specialist; 14 percent selected public librarian. Twenty percent of the middle school students indicated that their friends encouraged them to read. This was true for only 10 percent of the high school students.

\section{Discussion}

A number of themes emerged from the data. First, these urban teenagers appear to be reading. In general, 72 percent of them indicated that they read in their leisure time, albeit for some readers it might be only an occasional pursuit. It seems that when educators expand their definition of reading beyond "literary fiction," they find that young adults continue to read in their spare time despite the time pressure and social pressure they experience. 
The students also appear to recognize the value of reading. In their comments to the open-ended survey questions and the interview prompts, many of the students acknowledged the importance of reading to their success in school, college, and the workforce. While the majority seemed to view reading as a "quest for information" or "means to an end," there were some who saw reading as "an experience," or as Probst (1988) describes it, "a process of self-creation" (p. 21).

Most of the students view reading as a solitary activity. For the most part they do not see themselves as part of a community of readers. When asked if they ever talked to their friends about the things they were reading, most responded no. The only discussions they reported having with teachers revolved around the books they were reading for class. According to Hynds (1990), when students "do not envision themselves as members of a literate community, they generally do not develop literate behaviors (p. 255)."

Not surprisingly, the students prefer reading materials that are relevant to their livesmagazines that deal with topics of interest to them, books about teenagers like them, and the Internet which they view as not only providing more relevant, up-to-date information, but doing so in a "social" manner. This is consistent with Hynds's (1990) research which found that when teenagers read for pleasure they are searching for materials that will entice them to engage and maintain their interests.

The students appear to read very little during the summer. This is particularly troubling since research shows that summer reading is critical to summer learning, especially for low performing and/or disadvantaged students, like those in the two middle schools (Allington \& McGill-Franzen, 2003; Kim, 2004).

Finally, librarians seem to have minimal influence on the leisure reading behaviors of these teens. This may be due to the fact that most of the study participants said they visit libraries primarily to complete research projects for school. This means their interactions with librarians are most often related to the research process-locating and evaluating resources that support the curriculum-rather than to leisure reading.

\section{Implications}

\section{For Educators}

Scherer (2005) challenges educators to look to urban schools for solutions to their problems. The urban teenagers who took part in this study provided several strategies educators might use to better support teen literacy development.

- Utilize teens' social relationships to build interest and enthusiasm for reading. Employ a reader response-centered approach to literacy instruction. Create book clubs. Use the Internet-listservs, blogs, wikis, and social networking sites - to support student conversations about books. As Aronson (2001) points out, "whenever teenagers get to books, and get to talk about them, the results are amazing" (p. 106).

- Include more of the types of materials students prefer to read in libraries and classrooms. As Allington (1994) points out, personal interest "remains the most potent factor in the development of reading processes" (p. 21). 
- Determine how to utilize materials such as magazines, graphic novels, and the Internet to teach and reinforce the reading strategies that academic discourses and disciplinary fields such as science, mathematics, and the social sciences require.

- Expand the literature used in English classrooms to include literature to which students can relate. According to Rosenblatt (1991) if we want students to become lifelong readers, "the language, the setting, the theme, the central situation...must hold out some link with the young reader's past and present preoccupations, anxieties, emotions" (p. 72).

- Provide time during the school day for leisure reading. This is particularly important for economically disadvantaged urban students who often have to work to improve financial conditions at home, and may not have a place or the resources to read texts of their choice outside of school (Fisher, 2004).

- Aggressively market books and other reading materials to urban teens. Booktalks, podcasts, book trailers, and book clubs are all excellent ways to introduce teens to appealing reading material. Additionally, Tatum (2005) suggests that educators develop lists of "must-read" texts for minority teens whose literacy needs are often intertwined with cultural, social, and emotional factors.

- Adequately fund school and classroom libraries. For students in low income areas, school is the primary source for students' reading materials (Worthy et al., 1998); yet urban school districts are less likely to adequately fund school libraries than their suburban counterparts (NCES, 2005). Neuman and Celano (2001) analyzed school libraries in both low-income and middle-income neighborhoods and found that the students who were most likely to benefit from school libraries were offered the poorest services and resources and the least access. Similarly, classroom libraries in low income communities tend to be smaller. Duke (2000) found that classroom libraries in low-income school districts were about 40 percent smaller than those in high-income school districts, with fewer new books being added every year.

- Actively promote summer reading. Perhaps the first step is to increase access to books and other reading materials in the summer for urban youth. Access to books has been found to be positively associated with the amount of independent reading students do in the summer (Kim, 2004), yet there is large disparity between access based on socioeconomic status and ethnicity (Ferguson, 2002; Neuman \& Celano, 2001).

- Partner with parents to promote and encourage leisure reading. Several studies show that parents play a significant role in developing and sustaining the leisure reading habits of children and adolescents (Kim, 2004; Milam, 2003; Strommen \& Mates, 2004). Chandler (1999) found that this was particularly true for students from working class backgrounds who often experience confusion because of a disconnect between literary experiences at home and school.

- Be passionate about your love of reading! In order to sustain and encourage the reading habits of adolescent readers, educators must engage with them. Join students in their reading conversations by letting them know what you read when you are on vacation, riding the train to work, or preparing for bed. Display the books you are currently reading. 


\section{For Researchers}

Tatum (2005) identifies action research as a particularly promising way to discover how to address the literacy needs of urban youth. The questions he suggests, although directly related to the literacy development of black male adolescents, can be adapted to the broader urban adolescent community.

1. What happens to the literacy behaviors of urban teenagers when they are given a wide choice of reading materials? When educators broaden their definition of literacy to include non-traditional resources?

2. How can culturally relevant trade books, graphic novels, magazines, newspapers, and websites be used to teach in the content areas?

3. How can the websites of authors and illustrators representing various minority groups be used to advance the literacy of urban teenagers?

4. How can the voices of urban teenagers be effectively used to encourage urban teenagers to engage in reading and writing?

5. How can technology be used to support the literacy development of urban teenagers?

6. How can school and public libraries work with parents and other stakeholders in the community to support summer reading?

7. How can current events in the community be used to advance the literacy of urban teenagers?

\section{Concluding Thoughts}

As Tatum (2005) points out, there are no simple solutions; one method cannot fix all that needs to be fixed" (p. 153). However, by collaborating with urban teenagers to understand and address their leisure reading interests, educators can have a transformative effect on their lives and the lives of their families. Giving voice to urban teens - taking serious their ideas and opinions about leisure reading and literacy-may not only help educators better meet their literacy needs, but it may also empower these teens to take an active role in their educations and in their communities.

\section{Notes}

1. The results of Part 1 have been published separately in, Hughes-Hassell, S., \& Lutz, C. (2006). "What do you want to tell us about reading? A survey of the habits and attitudes of urban middle school students toward leisure reading." Young Adult Library Services, 4(2), 39-45.

2. The results of Part 2 have been published separately in, Hughes-Hassell, S. \& Rodge, P. (2007). "The leisure reading habits of urban adolescents." Journal of Adolescent and Adult Literacy, 51 (1), 22-34.

\section{References}

Allington, R.L. (1994). What's special about special programs for children who find learning to read difficult? Journal of Reading Behavior, 26(1), 95-115. 
Allington, R.L., \& McGill-Franzen, A. (2003). The impact of summer setback on the reading achievement gap. Phi Delta Kappan, 85(1), 68-75.

Anderson, R.C., Fielding, L.G., \&Wilson, P.T. (1988). "Growth in reading and how children spend their time outside of school.” Reading Research Quarterly, 23, 285-304.

Aronson, M. (2001). Exploding the myths: The truth about teenagers and reading. Lanham, MD: Scarecrow Press.

Balfanz, R., Spiridakis, K., \& Neild, R.C. (2002). Will converting high-poverty middle schools to K-8 schools facilitate achievement gains? A research brief for the School District of Philadelphia. Philadelphia, PA: Philadelphia Education Fund.

Biancarosa, C., \& Snow, C. E. (2006). Reading next-A vision for action and research in middle and high school literacy: A report to Carnegie Corporation of New York (2nd ed.).Washington, DC: Alliance for Excellent Education.

Chandler, K. (1999). "Reading relationships: Parents, adolescents, and popular fiction by Stephen King." Journal of Adolescent and Adult Literacy, 43(3), 228-239.

Cullinan, B.E. (2000). "Independent reading and school achievement.” School Library Media Research, 3 , Retrieved March 5, 2005 from http://www.ala.org/ala/aasl/aaslpubsandjournals/slmrb/slmrcontents/volume32000/independent.htm.

Cunningham, A.E., and K.E. Stanovich. (1991). "Tracking the unique effects of print exposure in children: Associations with vocabulary, general knowledge, and spelling." Journal of Educational Psychology, 83(2), 264-274.

Duke, N.K. (2000). "For the rich it's richer: Print experiences and environments offered to children in very lowand very high-socioeconomic status first-grade classrooms." American Educational Research Journal, $37(2), 441-78$.

Ferguson, R. F. (2002). What doesn't meet the eye: Understanding and addressing racial disparities in highachieving suburban schools. Naperville, IL: North Central Regional Educational Laboratory.

Fisher, D. (2004). Setting the 'opportunity to read' standard: Resuscitating the SSR program in an urban high school. Journal of Adolescent and Adult Literacy, 48(2), 138-150..

Hart, P. (2001). National Education Association (NEA) poll of the reading habits of adolescents. NEA. Retrieved December 19, 2001 from http://www.nea.org/readingmatters/readpoll.html

Hynds, S. (1990). Reading as a social event: Comprehension and response in the text, classroom, and world. In. D. Bogdan \& S.B. Straw (Eds.), Beyond communication: Reading comprehension and criticism (pp. 237-256). Portsmouth, NH: Boyton/Cook.

Kaczmarek, N., \& Stachowiak, M. (2004). Independent reading is key to lifelong learning. Momentum, 35(1), 54-58.

Kim, J. (2004). Summer reading and the ethnic achievement gap. Journal of Education for Students Placed at Risk, 9(2), 169-188.

Krashen, S. Do teenagers like to read? A comment on literacy campaigns. Retrieved November 12, 2001 from http://www.languagebooks.com/education/.

Krashen, S. (1993). The power of reading: Insights from the research. Englewood, CO: Libraries Unlimited.

Krashen, S. (2004). The power of reading: Insights from the research. (2 ${ }^{\text {nd }}$ ed.) Portsmouth, NH: Libraries Unlimited. 
Manzo, A.V., \& Manzo, U.C. (1995). Teaching children to be literate. Fort Worth, TX: Harcourt Brace College Publ.

McGrath, A. (2005, February 28). A new read on teen literacy. U.S. News and World Report. Retrieved May 5, 2008, from http://www-origin.usnews.com/usnews/culture/articles/050228/281iteracy.htm.

McKenna, M., Kear, D., \& Ellsworth, R. (1995). "Children's attitudes toward reading: A national survey." Reading Research Quarterly, 9, 934-956.

Mellon, C.A. (1987). Teenagers do read: What rural youth say about leisure reading. School Library Journal (Feb): 27-30.

Meyers, S. (2005). Twilight. Little Brown.

Milam, P. (2003). Scientifically based reading research: Implications for instruction. School Library Media Activities Monthly, 20(2), 20-22, 26.

Moffit, M. S., \& Wartella, E. (1992). "Youth and reading: A survey of leisure reading pursuits of female and male adolescents." Reading Research and Instruction 31(2), 1-17.

National Center for Education Statistics (NCES). (2007). Nation's report card: Reading 2007. Washington, D.C.: U.S. Government Printing Office. Retrieved May 9, 2007 from http://nces.ed.gov/nationsreportcard/pdf/main2007/2007496_3.pdf

National Center for Education Statistics. (NCES) (2005). School library media centers: Selected results from the education longitudinal study of 2002 (ELS: 2002). Retrieved March 5, 2005 from http://nces.ed.gov/pubs2005/2005302.pdf.

Neuman, S.B., \& Celano, D. (2001). “Access to print in low- and middle-income communities: An ecological study of 4 neighborhoods." Reading Research Quarterly, 36, 8-26.

Nipped, M., Duties, J.K., \& Larsen, J. (2005). "Literacy as a Leisure Activity: Free-Time Preferences of Older Children and Teenagers." Language, Speech and Hearing Services in Schools, 36 (April), 93-102.

Probst, R.E. (1988). Response and analysis: Teaching literature in junior and senior high school. Portsmouth, NH: Boynton/Cook.

Rosenblatt, L.M. (1991). Literature as exploration (4th ed.). New York: MLA.

Reutzel, D. R., \& Hollingsworth, P. M. (1991). "Investigating topic-related attitude: Effect on reading and remembering text." Journal of Educational Research, 84, 334-44.

Scherer, M. (2005). “Our cities, ourselves.” Educational Leadership, 62(6), 7.

Schoenbach, R., Greenleaf, C., Cziko, C., \& Hurwitz, L. (2000). Reading for understanding: A guide to improving reading in middle and high school classrooms. San Francisco: Jossey-Bass.

Searls, D.T., Mead, N.A., \& Ward, B. (1985). "The relationship of students' reading skills to TV watching, leisure reading, and homework." Journal of Reading, 29, 158-62.

Short, K.G. (Ed.). (1995). Research and professional resources in children's literature: Piecing a patchwork quilt. Newark, DE: International Reading Association.

Simpson, A. (1996). "Fictions and facts: An investigation of the reading practices of girls and boys." English Education, 28(4), 268-279.

SmartGirl.Com. Teen read week survey (a partnership of SmartGirl and the American Library Association): Summary of major findings. Retrieved December 19, 2001 from http://www.smartgirl.com/pages/speak/trwsummary.html. 
Strommen, L.T., \& Mates, B.F. (2004). Learning to love reading: Interviews with older children and teens." Journal of Adolescent and Adult Literacy, 48(3), 188-200.

Tatum, A.W. (2005). Teaching reading to black adolescent males: Closing the achievement gap. New York: Stenhouse.

Worthy, J., Turner, M., \& Moorman, M. (1998). “The precarious place of self-selected reading." Language Arts, 75(4), 296-304.

\section{Biographical Note}

Sandra Hughes-Hassell is an associate professor in the School of Information and Library Science at The University of North Carolina at Chapel Hill. Her research interests include delivery of information services to children and young adults, multicultural literature, information needs of disadvantaged youth, and the role of school library media specialists in education reform.

\section{Statement of Originality}

This statement certifies that the paper above is based upon original research undertaken by the author and that the paper was conceived and written by the author(s) alone and has not been published elsewhere. All information and ideas from others is referenced. 